\title{
Strategies for Building Information Modelling Adoption in the South African Construction Industry
}

\author{
Tawakalitu Bisola Odubiyi ${ }^{1 *}$, Clinton Aigbavboa ${ }^{1}$, Wellington Thwala $^{1}$, and Nendy Netshidane ${ }^{1}$ \\ ${ }^{1}$ SARChl in Sustainable Construction Management and Leadership in the Built Environment, \\ Faculty of Engineering and the Built Environment, University of Johannesburg \\ *Corresponding author's e-mail: kalitutawa@gmail.com
}

\begin{abstract}
The present state of the construction industry worldwide requires continual improvement. The quest for improvement is to the advantage of all concerned stakeholders. Innovation has been identified as this improvement measure. Building Information Model (BIM) is an example of such innovation in the construction industry. This work presents the strategies required for full adoption of BIM among construction professionals in South Africa. The study conducted a questionnaire survey among construction professionals in Gauteng province, South Africa. Data gathered were analyzed using percentage, mean item score and Kruskal-Wallis H-Test. The reliability of the questionnaire was also determined using Cronbach-alpha test. Embracing BIM requirements in construction supply chain, encouraging stakeholders collaboration, clear understanding of procurement process, and interpretation of accurate information are identified as key strategies for proper BIM adoption in for construction activities in South Africa.
\end{abstract}

\section{KEYWORDS}

BIM; Strategies; adoption; Innovation; South African Construction industry.

\section{INTRODUCTION}

Building Information Modelling (BIM) is a construction innovation that has come to stay. Information communication and technological innovation like BIM requires strategies for adoption. These strategies are required for planning and coordination. This is because there are challenges and tactics posed on design management and project delivery (Senthilkumar and Varghese, 2013). Hence, from a holistic perspective, there is a link between innovation type and these strategies.

Innovation has its governing principle. Stakeholders' collaboration is necessary for innovation to thrive (Wortmann et al, 2016). Communication, understanding of design information and support among project members too affects innovation like the Building Information Modelling. Globally, BIM is a system that links different Architectural Engineering and Construction (AEC) professions. It changes traditional methods of supply chain process and project delivery (Ibem and Laryea, 2015 and Irizarry et al., 2013). BIM allows for better collaboration and progressive methods of working between designers and engineers. 
BIM has been in the spotlight since the turn of the new thousand years. BIM programming bundles like "TEKLA", "AUTODESK REVIT" and "ARCHICAD BIM" have to this point been applied as part of distinctive development projects in South Africa. The functionality to have the Federation Intenationale de Football Association (FIFA) 2010 world cup in South Africa was a good start. This gave the AEC segment a chance to use the BIM innovation. This avenue gave South Africa a specific opportunity in Africa to display the use of BIM. After this occurrence, there has been the use of BIM across the country (Gerbich, 2010). Also, the use of 3D on Royal Bafokeng stadium, the new Mbombela Stadium, Nelspruit in Mpumalanga Province and steel rooftop structure of Nelson Mandela Bay Stadium, Port Elizabeth among others have been noticed in public infrastructure construction in South Africa (Gerbich, 2010). However the rate of adoption of this innovation is slow compared to developed countries (Wortmann et al., 2016). This calls for an improved strategy for effective adoption of BIM.

Literatures have addressed the numerous advantages of BIM adoption. Studies also have pointed out the drivers for its adoption. They are understood majorly from the theoretical view. However to rank and evaluate the importance of these drivers have been constrained by quantitative evidences (Eadie et al., 2013). These drives change across various BIM adoption phases. Public construction works in developed countries like the UK, USA, are currently on this track (GSA, 2015). The diffusion of an innovation like BIM depends on strategies to improve its growth after its initial adoption. They include use of scientific approach, government enforcement of use of BIM guideline, stakeholders, public and private collaboration, use of supply chain process and advanced procurement for designs, proper result interpretation, and documentation through professional groups (GSA, 2014; Glemma, 2013; Migilinskas et al., 2013, Singh et al., 2011; Slaughter 2000). Therefore, BIM implementation requires a technological paradigm shift across both developed and developing countries.

Improvement and implementation of countrywide BIM implementation in germane. There is therefore a key relationship between the public and private sector. In this context, both defined as the government and private businesses respectively. The government can enforce BIM improvement techniques, organise trainings and also provide resources needed (Raut and Valunjkar, 2017; Olatunji, 2011; Wong et al., 2011; McAdam, 2010). The private sector helps in growing new business methods and possibilities (Succar, 2009). It is argued that a collaborative effort between the public and private will boost BIM implementation. Yet, BIM frameworks are more important tools that influences its investment. BIM framework tools needs to overcome too common guideline problems and BIM benefit evaluation (Jrade and Lessard, 2015; Succar et al., 2012; Barlish and Sullivan, 2012; Succar 2009). In the South African market, BIM is termed "immature". Therefore joint effort among the concerned stakeholders will help BIM innovation overcome barriers. This study seeks to identify strategies for proper BIM adoption in South African construction industry. This knowledge will help understand better construction processes in South Africa.

\section{METHODS}

The study discussed the strategies for adopting BIM in the South African Construction industry. It employed a quantitative approach through a well-structured questionnaires administered to construction professionals in Gauteng province. Questionnaire is used because it provides a 
standardized view across all subject (Brace, 2011). The participants were construction professionals in Gauteng province, South Africa. 55 professionals took part in the survey, they include Quantity Surveyors, Mechanical Engineers, Electrical Engineers, Project Mangers, Construction Managers, Civil Engineers and Architect. They had experiences which could be less than 5 years or more than 20 years.

The questionnaire was divided into two sections. The first section discussed the background information of the respondents. Percentage was used to rank the background information. The other part were on the strategies for adopting BIM in South African construction industry. A fivelevel Likert scale was used to rate responses in this section. 1 is Strongly Disagree, 2 is Disagree, 3 is Neutral, and 4 stands for Agree while 5 is strongly agree. A MIS value above 3.0 represents the degree of significance of variables. Kruskal-wallis $\mathrm{H}$ test was conducted to check the consistency in the opinion of the group of respondents. Non-parametric test is appropriate for testing the significant difference or relationship existing in the view of two or more groups of respondents (Pallant, 2007) The internal consistency of the questionnaire used was also tested using the Cronbach's alpha test whose values ranges between 0 and 1 , and the higher value, the higher degree of internal consistency. The Cronbach's alpha value of 0.612 was derived for the different strategy variables as the derived value tends to 1.0 , the questionnaire is reliable.

\section{RESULTS AND FINDINGS \\ Biographical data}

The result on the biographical data of respondents showed $45 \%$ female and $55 \%$ male. Qualification revealed that 7\% had Doctorate degree, 13\% had Master's degree, $15 \%$ of them had Honors, 25\% Bachelor's degree, and 29\% had national Diplomas. The professional status of the respondents revealed that 24\% of were Quantity Surveyors, 18\% Mechanical Engineers, 9\% Industrial Engineer, 7\% Electrical Engineer, 7\% Construction Project Managers, 16\% Construction Managers, 24\% Civil Engineers, and 6\% were architects. Furthermore, these professionals were categorized as contractors (40\% of population), Consultants (35\%) and Government workers that were $25 \%$ of the population. These respondents all met the years of experience requirement.

\section{Strategies for the adoption of BIM in South African Construction Industry}

Result in Table 1 shows the mean score, chi square value and significant p-value derived from Kruskas- Wallis $\mathrm{H}$ Test for the variables serving as strategies. Kruskas- Wallis test is used to ascertain if there is a significant difference in the view of the category of professionals (Contractor, Consultant and those working for the government) on the variables serving as strategies. Result in Table 1 shows that at $99 \%$ confidence intervals, there is no significant difference in the view these professionals ( $p$ value 0.01 ) as the all have a significant $p$-value of above 0.01 . Therefore, the result from the mean score can be upheld as no variation exist in the opinion of the respondents.

Result from the analysis has the variables ranked according to their mean score. All the variables have mean value above 3.0. This shows all variables were important strategies for BIM implementation in South African Construction Industry. However, the most significant are, to embrace the BIM requirements in the construction supply chain (MIS 4.04), encourage 
stakeholders' collaboration (MIS 4.04), clear understanding of the procurement process (MIS 4.02), and providing clear understanding and interpretation of accurate information (MIS 4.02).

Construction project are generally unique and different. This makes the supply chain different from project to project. As such there is increasing level of competition which calls for improved integration process through BIM. Integrating BIM can help improve the visual monitoring of construction supply chain (Irizarry et al., 2013). Also, increased uptake of e-procurement facilities in South Africa is necessary (Iben and Laryea, 2015). Another literature states that BIM and Supply chain can partner by integration the features of BIM properly (Papadonikolaki et al., 2017). This strategy will propel BIM adoption in this context.

Construction process is a hub of team efforts and collaboration. BIM requires stakeholders' collaboration to function (Smith, 2014). This is because BIM enables close collaboration and integration among project stakeholder (Azhar et al., 2012). Such integration will then give a positive change to projects through, trust, technology and communication among stakeholders. However, South Africa lags behind the developed countries in BIM use since there are no standard BIM protocols for cross-industry collaboration (Wortmann et al, 2016). Yet, the findings agrees that people management is key to implementing BIM (Liao and Leo, 2018; Singh et al., 2011)

A proper understanding and interpretation of BIM is vital. There is a need to standardize BIM process and define procedure for its utilization (Azhar et al., 2012). This will aid BIM to be properly adopted. As such, in South Africa it is necessary to have consistent BIM understanding (Wortmann et al., 2016). Proper BIM standards will enable clear understanding and interpretation of accurate Information.

Table 1. Strategies for full BIM adoption in South African construction industry

\begin{tabular}{|c|c|c|c|c|}
\hline Variables & MIS & RANK & $\begin{array}{c}\text { CHI- } \\
\text { SQUARE }\end{array}$ & $\begin{array}{c}\text { P- } \\
\text { VALUE }\end{array}$ \\
\hline $\begin{array}{l}\text { Embrace the BIM requirements in the } \\
\text { construction supply chain }\end{array}$ & 4.04 & 1 & 1.342 & 0.511 \\
\hline Encourage stakeholders collaboration & 4.04 & 2 & 3.210 & 0.201 \\
\hline $\begin{array}{l}\text { Clear understanding of the procurement } \\
\text { process }\end{array}$ & 4.02 & 3 & 2.300 & 0.317 \\
\hline $\begin{array}{l}\text { Provide clear understanding and interpretation } \\
\text { of accurate information }\end{array}$ & 4.02 & 4 & 4.053 & 0.132 \\
\hline $\begin{array}{l}\text { Provide continuous employee training about } \\
\text { BIM }\end{array}$ & 3.98 & 5 & 4.414 & 0.110 \\
\hline $\begin{array}{l}\text { Collaboration between public and private } \\
\text { sector }\end{array}$ & 3.98 & 6 & 1.848 & 0.397 \\
\hline Implementation by the government & 3.95 & 7 & 0.238 & 0.888 \\
\hline Commitment through investment for BIM & 3.95 & 8 & 0.841 & 0.657 \\
\hline $\begin{array}{l}\text { Evaluation of contemporary methods and } \\
\text { equipment }\end{array}$ & 3.95 & 9 & 2.348 & 0.309 \\
\hline $\begin{array}{l}\text { Identification of the type of the group and } \\
\text { software to use }\end{array}$ & 3.91 & 10 & 3.060 & 0.217 \\
\hline
\end{tabular}


MOC SUMMIT / MAY 2019

\begin{tabular}{lcccc} 
Certain training to implementation of latest & 3.87 & 11 & 0.713 & 0.700 \\
equipment & 3.8 & 12 & 5.023 & 0.081 \\
Actual use & 3.69 & 13 & 0.163 & 0.922 \\
\hline Post-use evaluation &
\end{tabular}

\section{CONCLUSION}

This study addressed the strategies for BIM adoption in South African construction industry. It identified the key strategies for proper BIM adoption in South African construction industry using a quantitative approach. Based on these findings, this study concludes that the key strategies for proper BIM adoption are to embrace BIM requirements in construction supply chain, encourage stakeholders' collaboration, and provide clear understanding of procurement process and, clear understanding and interpretation of accurate information. Therefore, the study recommends that BIM processes should be well designed to partner with supply chain processes. This can be done by understanding that both process are an integration. Also, the need to move to better stakeholders' collaboration is necessary for this new innovation. This is possible through aggressive sensitization for all stakeholders. Standard and consistent BIM protocol is necessary tool for BIM understanding and interpretation. Proper training should be given to user while manufacturers of BIM applications should also align and simplify BIM concepts. This study further recommends a study on practices and skills necessary for BIM adoption strategy adoption. This study has been able to contribute to the body of knowledge by strategies for proper BIM in South African construction industry. A consideration of the findings and recommendation will contribute to BIM adoption within the country.

\section{REFERENCES}

Azhar, S., Khalfan, M. \& Maqsood, T. (2012). "Building Information Modelling (BIM): Now and Beyond." Australian Journal of Construction Economics and Building, 12(4), 15-28.

Barlish, K. and Sullivan, K. (2012). "How to measure the benefits of BIM - A case study approach." Automation in Construction, 24, 149-159.

Brace, I. (2008). "Questionnaire Design: How to plan, structure and write survey material for effective market research" (2nd ed.). London and Philadelphia: Kogan page Limited.

Eadie, R., Odeyinka, H., Browne, M., Keown, C. and Yohanis, M. . (2013). "An analysis of the drivers for adopting Building Information Modelling." Journal of Information in Technology in Construction, 18, 338-352.

Gerbich, C. (2010, June 13). "Construction week online.” Retrieved January 1, 2019, from Digital Construct: http://www.constructionweekonline.com/article-8633-up-for-the-cup

GSA. (2015, June 2). "BIM Guide 05 Energy performance". U.S. General Services Administration, pp. 1-76.

Ibem, E.O., and Laryea, S. (2015). "Ee-procurement use in the South African Construction industry." Journal of Information Technology in construction (ITCon), 364-384.

Irizarry, J., Karan, E. P., and Jalaei, F. (2013). "Integrating BIM and GIS ti improve the visual monitoring of construction supply chain management." Automation in Construction, 241254. 
Jrade, A. and Lessard, J. (2015). "An Integrated BIM System to Track the Time and Cost of Construction Projects: A Case Study. . Journal of Construction Engineering, 10, 1-12.

Liao, L., and Teo, E.A.L. (2018). "Organizational change perspective on people managemnet in BIM implementation in Building projects.” Journal of Management in Engineering, 34(3).

Migilinskas, D., Popov, V., Juocevicius, V. \& Ustinovichius, L. (2013). "The benefits obstacles and problems of practical BIM implementation." Procedia Engineering, 57, 767-774.

Olatunji, O. A. (2011). "A Preliminary review of the legal implications of BIM and model ownership." Journal of Information Technology in Construction, 16, 687-695.

Pallant.J. (2007). "SPSS survival manual: A step-by-step guide to data analysis using SPSS version 15". Nova iorque: McGraw hill.

Papadonikolaki, E., Verbraeck, A., and Wamelink, H. (2017). "Construction Management." Construction Managemnt and Economics, 35(8-9), 531-552.

Senthilkumar, V. and Varghese, K. (2013). "Case study-based testing of Design Interface Management System." Journal of Management in Engineering, 29, 279-288.

Slaughter, E. S. (2000). "Implementation of construction innovations." Building Research \& Information, 28(1), 2-17.

Smith, P. (2012). "BIM implementation -global initiatives and creative approach." Creative Construction Conference, (pp. 605-612). Prague.

Wortmann, A.E., Root, D.S., and Venkatchalam, S. (2016). "Modelling (BIM) standards and specifications around the world and its applicbility to the South African AEC sector: A criticl review." proceedings of the 1st international BIM Academic Forum (BAF).

Fisher, J.W., and Struik, J.H.A. (1974) Guide to Design Criteria for Bolted and Riveted Joints. Wiley, New York, NY, USA.

Kurtz, M. (1991). "Section 7: Transformation of space in computer graphics." In Handbook of Applied Mathematics for Engineers and Scientists. McGraw-Hill, New York, NY, USA, 7.17.42 .

Mossberg, W.S. (1993). "Word isn't perfect but new WordPerfect is too much for words." Wall Street Journal. Dec. 2, B1.

Pennoni, C.R. (1992). "Visioning: The future of civil engineering." Journal of Professional Issues in Engineering Education and Practice, 118(3), 221-233. 